\title{
Spiritual Intelligence Moderates the Relationship Between Psychological Well- Being, Role Stress and Auditor Performance
}

\author{
Thahira Qarimma Nursabilla ${ }^{1}$ \\ Fakultas Ekonomi dan Bisnis \\ Universitas Udayana, Indonesia \\ Herkulanus Bambang Suprasto $^{3}$
Fakultas Ekonomi dan Bisnis
Universitas Udayana, Indonesia
}

\author{
Gayatri $^{2}$ \\ Fakultas Ekonomi dan Bisnis \\ Universitas Udayana, Indonesia \\ Maria Mediatrix Ratna Sari ${ }^{4}$ \\ Fakultas Ekonomi dan Bisnis \\ Universitas Udayana, Indonesia
}

Surel : thahirabella@gmail.com

\section{ABSTRACT}

The purpose of this study is to investigate the impact of psychological well-being and role stress on auditor performance, with spiritual intelligence serving as a moderating variable. The data collection for this study was obtained from a questionnaire and was collected at the Bali Province Public Accountant Office. The sample was determined using a purposive sampling method with 54 auditors from the Bali Province Public Accountants as respondents. In this study, the interaction test MRA was used to analyze data. According to the findings of the study, psychological well-being has a positive effect on auditor performance. This research also shows that role stress can impair auditor performance. Auditors' spiritual intelligence has the potential to strengthen the relationship between psychological well-being and auditor performance. On the other hand, spiritual intelligence mitigates the impact of role stress on auditor performance.

Keywords: Psychological Well-Being; Stress; Auditor Performance; Spiritual Intelligence.

\section{Kecerdasan Spiritual Memoderasi Hubungan antara} Kesejahteraan Psikologis, Stres Peran dan Kinerja Auditor

\begin{abstract}
ABSTRAK
Tujuan dari penelitian ini adalah untuk mengetahui pengaruh kesejahteraan psikologis dan stres peran terhadap kinerja auditor, dengan kecerdasan spiritual sebagai variabel moderasi. Pengumpulan data dalam penelitian ini diperoleh dari kuesioner dan dikumpulkan di Kantor Akuntan Publik Provinsi Bali. Penentuan sampel menggunakan metode purposive sampling dengan responden 54 auditor dari Kantor Akuntan Publik Provinsi Bali. Dalam penelitian ini, uji interaksi MRA digunakan untuk menganalisis data. Menurut temuan penelitian, kesejahteraan psikologis berpengaruh positif terhadap kinerja auditor. Penelitian ini juga menunjukkan bahwa stres peran dapat mengganggu kinerja auditor. Kecerdasan spiritual auditor berpotensi memperkuat hubungan antara kesejahteraan psikologis dan kinerja auditor. Di sisi lain, kecerdasan spiritual mengurangi dampak stres peran pada kinerja auditor.
\end{abstract}

Kata Kunci: Psychological Well-Being; Stres; Kinerja Auditor; Spiritual Intelligence.

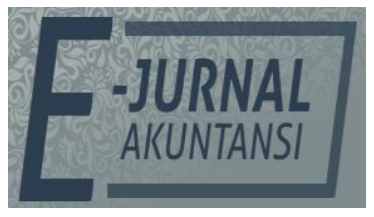

e-ISSN 2302-8556

Vol. 31 No. 6

Denpasar, Juni 2021

Hal. 1424-1437

DOI:

10.24843/EJA.2021.v31.i06.p06

PENGUTIPAN:

Nursabilla, T.Q., Gayatri, Suprasto, H.B., \& Sari, M.M.R. (2021). Spiritual Intelligence Moderates the Relationship Between

Psychological Well-Being, Role Stress and Auditor Performance. E-Jurnal Akuntansi, 31(6), 1424-1437

RIWAYAT ARTIKEL: Artikel Masuk: 10 April 2021 Artikel Diterima: 7 Mei 2021

Artikel dapat diakses : https://ojs.unud.ac.id/index.php/Akuntansi/index 


\section{INTRODUCTION}

The phenomenon of audit failure cases in the last few decades has created a crisis of public confidence regarding the inability of the accounting profession to audit financial statements. The emergence of this crisis is reasonable, because there are quite a few financial statements of a company that received an unqualified opinion, but instead went bankrupt after the opinion was issued. There have been 51 cases of major audit failure, from 1986 to 2010 (Nugroho, 2014)

Various cases of accounting scandals regarding audits have recently affected the performance of auditors and have had an adverse impact so that they can affect public confidence in public accountants. For example, the case happened to public accountant Marlinna and public accountant Merliyana Syamsul and Public Accounting Firm Satrio, Bing, Eny (SBE) and Partners who were deemed not to provide an opinion that was in accordance with the actual conditions in the annual audit financial report belonging to PT Sunprima Nusantara Pembiayaan (SNP Finance). The sanctions received by the two public accountants and one Public Accounting Firm were in the form of cancellation of registration related to the results of auditing SNP Finance financial statements. The two public accountants and one Public Accounting Firm gave an 'Unqualified' opinion in the audit results of SNP Finance's annual financial statements. In fact, the results of the OJK examination indicated that SNP Finance presented significant financial reports that were not in accordance with the actual financial conditions. Thus, causing losses to many parties, including banks. OJK Deputy Commissioner for Strategic Management and Logistics, Anto Prabowo, said that the sanctions imposed on the two public accountants and Public Accounting Firm apply to the banking sector, capital market and the non-bank financial industry. This means that temporarily they cannot carry out the financial services audit process. The cancellation of Public Accounting Firm Satrio, Bing, Eny (SBE) registration becomes effective after the Public Accounting Firm completes the 2018 Audit Annual Financial Report audit of clients who still have contracts (Syafina, 2018).

Auditor's performance is influenced by several factors, one of which is psychological well-being, someone who has good psychological well-being is one who is able to realize his / her potential on an ongoing basis, is able to accept himself as he is, able to establish warm relationships with other people, has independence, has meaning in life and able to control the environment (Quilim et al., 2016). Prosperity and happiness are something that every individual in this world wants to have. Psychological well-being is a multidimensional measure of psychological development and mental health, including a scale of levels of independence and positive relationships with other people (Wikanestri \& Prabowo, 2015). If the auditors can put their emotions in the right portion, sort out the satisfaction and set the mood and are supported by psychological well-being, they are expected to be able to improve their performance in carrying out their assignments. It is believed that the high level of work stress can be overcome by each individual, if each individual has good psychological well-being (Rizkia \& Reskino, 2015).

According to Ryff (1989) psychological well-being is a condition for individuals who have a positive attitude towards themselves and others. This positive attitude is characterized by the ability to make their own decisions and 
regulate their behavior. The individual concerned can also create and regulate an environment according to his needs, have a life goal and make life more meaningful and try to explore and develop himself, whereas according to Rijal \& Abdullah (2020) psychological well-being has no effect on auditors' performance.

Stress can have both positive and negative effects. There are two types of stress, namely eustress which has a positive impact on human life and distress which has a negative impact. Stress at a certain level can actually motivate someone to improve their performance and finish their work. However, excessive stress levels can have a negative impact which can lead to decreased performance, job dissatisfaction, and can lead to depression and anxiety (Wiryathi et al., 2014).

Role conflict and role ambiguity are quite influential in a job which is not only for the auditors themselves, in relation to work pressure, it will have an impact on job satisfaction that is not appropriate and decreases the level of performance of individuals who work in an organization so that it affects the resulting quality of work that is not in accordance with the expectations of the organization or each of these individuals. With good emotional management, the role stress experienced by auditors can be handled properly and it is likely that auditor performance will remain stable or even increase (Arfah \& Dahniar, 2019).

Several studies related to role conflicts and auditor performance have been conducted, such as research by Ermawati et al. (2014) and Susanti et al. (2017). Both of these studies and found the influence of role conflict perceived by auditors on their performance. Different research results were found by Cendana \& Suaryana (2018); Kembara (2014) who found that role conflict had no effect on auditor performance.

Spiritual Intelligence is intelligence to deal with and solve problems of meaning and value, namely placing the behavior and meaning of human life in a broader and richer context of meaning, and assessing one's actions and way of life as more meaningful than others. Spiritual intelligence does not have to be related to religion. In addition, spiritual intelligence causes a person to desire higher motivations and makes him act on these motivations. In previous research Akimas \& Bachri (2016) found that spiritual intelligence has a significant effect on employee performance, and according to Amarin \& Sukirman (2017) and Grece \& Latrini (2016) stated that spiritual intelligence has a positive effect on auditor performance. Meanwhile, according to Pratama (2014) spirituality partially does not have a significant effect on the performance of lecturers, and in line with research Anjarini (2018) found that there is no effect between spiritual intelligence and teacher performance.

From the inconsistent results of previous research, the researcher suspected that there were contingency factors that influenced the relationship between psychological well-being, Role Stress, and the performance of auditors in the accounting profession. Murray (1990) explains that in order to reconcile conflicting results, a contingency approach is needed to identify other variables that act as moderators or mediators in the research model. This study uses the spiritual intelligence variable as a moderating variable because spiritual intelligence is intelligence that shapes a person's character to be better and has deep meaning, and can be used as a benchmark to judge that one's way of life or actions is more meaningful than the way of life of others (Zohar \& Marshall, 2005). Spiritual 
intelligence focuses on the question why, this builds awareness of oneself and not on ideas, views or opinions or experiences. The focus on these questions will make auditors know the objectives to be achieved in carrying out their duties, so that auditors are more enthusiastic about carrying out these tasks (Bowell, 2005).

The motivation in this research is to examine the effect of spiritual intelligence and role stress on the performance of auditors with psychological well-being as moderator, as well as the use of different dimensions of time and place (confirmatory research). The difference in the time dimension in question is that the previous research was carried out in 2019 and in this study it was conducted in 2020, while the difference in the dimensions of the place was carried out by Mappanyukki (2019) at the Inspectorate Office of South Sulawesi Province, this research was conducted at the Bali Province Public Accountant Office.

Psychological well-being, someone who has good psychological well-being is one who is able to realize his / her potential on an ongoing basis, is able to accept himself as he is, is able to establish warm relationships with others, has independence, has meaning in life and is able to control the environment (Quilim et al., 2016). Prosperity and happiness are something that every individual in this world wants to have. Psychological well-being is a multidimensional measure of psychological development and mental health, including a scale of levels of independence and positive relationships with other people (Wikanestri \& Prabowo, 2015). If the auditor can put his emotions in the right portion, sort out the satisfaction and set the mood and is supported by the psychological well-being aspect of himself, it is expected that he will be able to improve his performance in carrying out his assignment. In line with Rahayu (2020) which states that psychological well-being has a significant effect on employee performance. Based on this description, a hypothesis can be drawn:

$\mathrm{H}_{1}$ : Psychological well-being has a positive effect on auditor performance

There are three elements of role stress as stated by Fogarty et al. (2000), namely role conflict, role ambiguity, and role overload. Ramadika et al. (2014) that role conflict arises because there are two different orders that are received simultaneously and the implementation of just one order will result in the neglect of the other. Role conflict can cause discomfort at work, and can reduce work motivation because it has an impact on individual behavior such as the emergence of work tensions, a lot of worker displacement, decreased job satisfaction so that it can reduce auditor performance. Winidiantari \& Widhiyani (2015) also state that role conflict has a significant negative effect on auditor performance.

Rosally \& Jogi (2015) stated someone can experience role ambiguity if they feel that there is no clarity regarding job expectations. Role ambiguity has a negative effect, meaning that when the role of the auditor becomes more unclear, the performance decreases and when the role ambiguity is lower, the auditor's performance will be higher. Kurniawan (2018) states that role ambiguity arises due to insufficient information needed to complete the assigned tasks or work in a satisfactory manner. In line with Iswarasari \& Kusumawati (2018), which states that role ambiguity occurs when a person does not have clear information, direction and goals regarding the role or tasks that must be carried out. This can lead to a person's lack of understanding of the privileges and obligations he has to do work so that it can erode self-confidence and hinder job performance. 
Role overload is a condition where a person has too much work to do or is under pressure from a tight time schedule. The absence of planning for workforce requirements can make auditors experience excess roles, especially during peak season when Public Accounting Firm will be flooded with work, and available auditor staff must do all work in the same time period (Ariyanto et al., 2020; Ramadika et al., 2014). Auditors who experience role overload can have an impact on their work results. As a result, a person is easily tired and is in high tension. This could reduce the performance of that person Amalia (2017). Based on the description above, the following hypothesis can be formulated:

$\mathrm{H}_{2}$ : Role stress has a negative effect on auditor performance.

Individuals who have psychological well-being have psychological wellbeing in the world of work is an important topic in shaping a person's behavior or a situation in the work environment. Psychological well-being plays an important role in overcoming role stress and improving auditor performance. It is believed that the high level of work stress can be overcome by each individual, if each individual has good psychological well-being. If the auditor can put his emotions in the right portion, sort out the satisfaction and set the mood and is supported by the psychological well-being aspect of himself, it is expected that he will be able to improve his performance in carrying out his assignment. It is believed that the high level of work stress can be overcome by each individual, if each individual has good psychological well-being (Rizkia \& Reskino, 2015). According to Ryff (1989) psychological well-being is a condition for individuals who have a positive attitude, both towards themselves and towards others. This positive attitude is characterized by the ability to make their own decisions and regulate their behavior. Meanwhile, according to Rijal \& Abdullah (2020) psychological wellbeing has no effect on auditor performance.

$\mathrm{H}_{3}$ : Spiritual Intelligence strengthens psychological well-being on auditor performance

Spiritual Intelligence moderates the effect of role stress on auditor performance based on role theory. In role theory emphasizes the character of the individual as a social actor who studies behavior in accordance with the position he occupies in the work environment and society. The concept of role theory reflects the position of an individual in the midst of society in a social system that has a relationship with rights and obligations as well as authority and responsibility (Putri \& Wirawati, 2020; Wiguna \& Yadnyana, 2019). Everyone has a role, whether in the family, work or social community, where in each of these roles they have different behaviors. Spiritual intelligence is intelligence that shapes a person's character to be better and has deep meaning, and can be used as a benchmark to judge that one's way of life or actions is more meaningful than the way of life of others.

Individuals who have a certain level of stress can actually motivate someone to improve their performance and finish their work. However, excessive stress levels can have a negative impact which can lead to decreased performance, job dissatisfaction, and can lead to depression and anxiety (Wiryathi et al., 2014). With good emotional management, the role stress experienced by auditors can be handled properly and it is likely that auditor performance will remain stable or even increase (Arfah \& Dahniar, 2019). role conflicts and auditor performance have 
been carried out, such as research by Ermawati et al. (2014); Susanti et al. (2017). Both of these studies and found the influence of role conflict perceived by auditors on their performance. Different research results were found by Cendana \& Suaryana (2018) and Kembara (2014) who found that role conflict had no effect on auditor performance. Based on this description, a hypothesis can be drawn:

$\mathrm{H}_{4}$ : Spiritual intelligence weakens role stress on auditor performance.

\section{METODE PENELITIAN}

The location of this research is at the Public Accounting Firm in Bali Province in 2020 and has been registered in the Directory published by the Indonesian Institute of Public Accountants (IAPI). The location was chosen to facilitate data collection because public accounting firms registered in the Directory will easily find out their names and addresses. Public Accounting Firms registered in the IAPI Directory have obtained permission from the Minister of Finance of the Republic of Indonesia as a forum for public accountants to carry out their work.

Based on the source, the type of data used in this study is primary data collected through a questionnaire in the form of statements and cases related to psychological well-being, role stress, auditor performance and spiritual intelligence. Based on its nature, the data used in this study is quantitative data which includes the score data which was answered by auditor respondents by visiting the Bali Province Public Accountant Office directly.

The population in this study were all auditors who worked at the Public Accounting Firm in Bali Province which were listed in the Directory published by the Indonesian Institute of Certified Public Accountants in 2019, with a total of 101 auditors. The sampling method in this research is purposive sampling method. Purposive sampling method, namely the selection of samples that do not provide equal opportunities or opportunities for each member or element of the population to be sampled by setting certain criteria or considerations. The criteria for determining the sample in this study were auditors who had participated in the audit team and had more than 1 year of work experience in public accounting firms.

Analysis of verification data using Moderated Regression Analysis. The regression equation model is as follows:

Information:

$$
Y=\alpha+\beta_{1} X_{1}+\beta_{2} X_{2}+\beta_{3} X_{3}+\beta_{4} X_{1} X_{3}+\beta 5 X_{2} X_{3}+\varepsilon
$$

Y : Auditor Performance

A : Constant

$\beta_{1} \beta_{2} \beta_{3}$ : Regression coefficient

$X_{1} \quad$ : Psychological Well-being

$\mathrm{X}_{2} \quad$ : Role Stress

$\mathrm{X}_{3}$ : Spiritual Intelligence

$\mathrm{X}_{1} . \mathrm{X}_{3}$ : Interaction between Psychological Well-being and Spiritual Intelligence

$\mathrm{X}_{2} . \mathrm{X}_{3}$ : Interaction between Role Stress and Spiritual Intelligence

$\varepsilon \quad$ : Standard error

\section{RESULT AND DISCUSSIONS}


Before the data analysis technique was carried out on the data collected, the research instrument was first tested, in this case the questionnaire validity and reliability were tested. Valid instruments indicate that the measuring instrument used to obtain data (measure) is valid. Valid means that the instrument can be used to measure what should be measured. A reliable instrument is an instrument that, when used several times to measure the same object, will produce the same data. Valid and reliable instruments are an absolute requirement to obtain valid and reliable research results (Sugiyono, 2017).

The results of the validity test show that all variables have a correlation coefficient value with a total score of all statement items greater than 0.30 . This shows that the statement items in the research instrument are valid.

The results of the reliability test in Table 1 . indicate that all research instruments, namely Psychological Well Being, Role Stress, Spiritual Intelligence, Auditor Performance have a Cronbach's Alpha coefficient of more than 0.60. It can be said that all instruments are reliable so that they can be used to conduct research.

Descriptive statistical analysis provides an overview or description of a data seen from the value of the minimum, maximum, mean, and standard deviation where $\mathrm{N}$ is the number of research respondents. The results of descriptive statistical analysis can be seen in Table 1.

\section{Table 1. Descriptive Statistic}

\begin{tabular}{lcrrrr}
\hline & N & Minimum & Maximum & Mean & Std. Deviation \\
\hline Psychological Well Being & 54 & 63.000 & 82.000 & 68.352 & 4.261 \\
Role Stress & 54 & 17.000 & 52.000 & 28.685 & 6.5985 \\
Spiritual Intelligence & 54 & 49.000 & 77.000 & 56.222 & 5.6657 \\
Auditor Performance & 54 & 33.000 & 50.000 & 40.074 & 2.4637 \\
Valid N (listwise) & 54 & & & & \\
\hline
\end{tabular}

Source: Processed Data, 2020

The Psychological Well Being variable has a minimum value of 63.00, a maximum value of 82.00, an average value of 68.3519 and a standard deviation value of 4.26109 . The average value is close to the maximum value of 82.00 . This shows that the Psychological Well Being in the Auditor Performance in KAP Bali Province has high psychological well-being.

The Role Stress variable has a minimum value of 17.00 , a maximum value of 52.00, an average value of 28.6852 and a standard deviation value of 6.59852 . The average value is close to the maximum value of 52.00. This shows that the role stress that exists in the performance of auditors in KAP Bali Province has low role pressure.

The Spiritual Intelligence variable has a minimum value of 49.00, a maximum value of 77.00, an average value of 56.2222 and a standard deviation of 5.66574. The average value is close to the maximum value of 77.00 . This shows that the Spiritual Intelligence in KAP Bali Province has high spiritual intelligence.

The Auditor Performance variable has a minimum value of 33.00, a maximum value of 50.00, an average value of 40.0741 and a standard deviation value of 2.46371 . The average value is close to the maximum value of 50.00 . This shows that the performance of auditors at KAP Bali Province has good performance results. 
To find out whether the Spiritual Intelligence variable is able to moderate the influence of Psychological Well-being and Role Stress on Auditor Performance, a Moderated Regression Analysis (MRA) model is used. This model aims to determine whether the moderating variable is able to influence the relationship between the independent variable and the dependent variable, where the regression equation contains an element of interaction (multiplication of two or more independent variables).

Table 2. Results of Moderation Regression Analysis

\begin{tabular}{lcrrrr}
\hline & $\begin{array}{c}\text { Expected } \\
\text { correlation }\end{array}$ & Coefficient & Std. Error & t-ratio & \multicolumn{2}{c}{$\mathrm{p}$-value } \\
\hline const & $?$ & 124.276 & 9.917 & 12.532 & $0.000^{* * *}$ \\
$\mathrm{X}_{1}$ & + & 0.459 & 0.069 & 6.687 & $0.000^{* * *}$ \\
$\mathrm{X}_{2}$ & - & -0.658 & 0.135 & -4.882 & $0.000^{* * *}$ \\
$\mathrm{X}_{3}$ & $?$ & 0.751 & 0.058 & 12.927 & $0.000^{* * *}$ \\
$\mathrm{X}_{1} . \mathrm{X}_{3}$ & + & 17.779 & 4.058 & 4.381 & $0.000^{* * *}$ \\
$\mathrm{X}_{2} . \mathrm{X}_{3}$ & - & -29.550 & 4.411 & -6.700 & $0.000^{* * *}$ \\
Adjusted $\mathrm{R}^{2}$ & -0.856 & & & \\
Sig. F & & 0.000 & & & \\
\hline
\end{tabular}

Note: $\mathrm{X}_{1}=$ Psychological Well-being; $\mathrm{X}_{2}=$ Role Stress; $\mathrm{X}_{3}=$ Spiritual Intelligence

Source: Processed Data, 2020

Based on Table 1, a moderation regression equation model can be made, which is as follows:

$$
\mathrm{Y}=124.276+0.459 \mathrm{X} 1-0.658 \mathrm{X} 2+0.751 \mathrm{X} 3+17.779 \mathrm{X} 1 . \mathrm{X} 3-29.550 \mathrm{X} 2 . \mathrm{X} 3
$$

Based on Table 1, it can be seen that the results of the Psychological Wellbeing variable statistical test obtained a regression coefficient of 0.459 with a significance level of $t$ of 0.000 based on the results of the statistical test, so hypothesis 1 which states that Psychological Well-being has a positive effect on auditor performance is accepted $\left(\mathrm{H}_{1}\right.$ accepted $)$. The test results obtained empirical evidence that $\mathrm{H}_{1}$ is supported by a positive coefficient, thus the first hypothesis $\mathrm{H}_{1}$ is accepted, namely, Psychological Well-being has a positive effect on auditor performance. The results of this study indicate that the high psychological wellbeing of an individual causes the individual to have good psychological well-being so that he is able to realize his / her potential on an ongoing basis, is able to accept himself as he is, able to establish warm relationships with others, has independence, has meaning in life. and able to control the environment.

The relationship between psychological well-being and the auditor's performance is based on objective setting theory. In goal-setting theory, it explains that a person's behavior is determined by two cognitions, namely values (values) and intentions (goals). If goals determine human business, the higher and more difficult the goals can be achieved, the higher the level of performance that is produced compared to goals that are easily achieved. Specific goals will result in a higher level of business than goals that are not clearly defined (vague goals). Incentives such as money, feedback, competition, and the like will not have an effect on behavior unless the incentive affects the setting and / or acceptance of difficult and specific goals.

The results of this study are consistent with research conducted by Rahayu (2020) which states that psychological well-being has a significant effect on 
employee performance. Based on the results of this study, it can be recommended to the auditors of the Public Accounting Firm in Bali Province to always motivate auditors regarding psychological well-being, where psychological well-being is a multi-dimensional measure of psychological development and mental health, including a scale of levels of independence and a positive relationship with other people.

Based on Table 1., it can be seen that the results of the statistical test for the variable Role Stress obtained a regression coefficient of -0.658 with a significance level of $t$ of 0.000 based on the results of the statistical test, so hypothesis 2 which states that Role Stress has a negative effect on auditor performance is accepted $\left(\mathrm{H}_{2}\right.$ is accepted). The test results obtained empirical evidence that $\mathrm{H}_{2}$ is supported by a negative coefficient, thus the second hypothesis $\mathrm{H}_{2}$ is accepted, namely, Role Stress has a negative effect on auditor performance. The results of this study indicate that there are three elements of role stress, namely role conflict, role ambiguity, and role overload. Role conflict can cause a feeling of discomfort at work, and can reduce work motivation because it has an impact on individual behavior such as work tensions, a lot of worker displacement, decreased job satisfaction, which can reduce auditor performance. A person's role ambiguity can experience role ambiguity if they feel that there is no clarity regarding job expectations. When the role of auditors is increasingly unclear, the performance will decrease and when the unclear roles are getting lower, the auditor's performance is getting higher. This can lead to a person's lack of understanding of the privileges and obligations he has to do work so that it can erode self-confidence and hinder job performance. The role overload of someone who is overloaded can have an impact on his work results. As a result, a person is easily tired and is under high pressure, because it can reduce the performance of that person.

The relationship between role stress and auditor performance is based on role theory. In role theory emphasizes the character of the individual as a social actor who studies behavior in accordance with the position he occupies in the work environment and society. The concept of role theory reflects the position of an individual in the midst of society in a social system that has a relationship with rights and obligations as well as authority and responsibility. Everyone has a role, whether in the family, work or social community, where in each of these roles they have different behaviors.

The results of this study are consistent with research conducted by Amalia (2017), Iswarasari \& Kusumawati (2018), Kurniawan (2018), Winidiantari \& Widhiyani (2015) which state that role stress has a negative effect on auditor performance. Based on the results of this study, it can be recommended to the auditors of the Public Accounting Firm in Bali Province to reduce the nature of the role stress for each auditor of the Public Accounting Firm in Bali Province so that their performance is getting better.

Based on Table 1., the results of moderation regression analysis show that the regression coefficient for Psychological Well-being $\left(\beta_{1}\right)$ is positive at 0.459 with a significance value of 0.000 and the regression coefficient value for the interaction variable $X_{1} . X_{3}\left(\beta_{4}\right)$ is positive at 17.779 with a significance value of 0.000 , indicating that there is an influence which is unidirectional because the independent variables and interactions have the same positive value. This means that the 
Spiritual Intelligence variable is a moderating variable that strengthens the influence of Psychological Well-being on auditor performance. The test results obtained empirical evidence that $\mathrm{H}_{3}$ is accepted, meaning that Spiritual Intelligence strengthens the influence of Psychological Well-being on auditor performance. This means that if an auditor has a high level of spiritual intelligence, it can improve the psychological well-being of auditors in the world of work. Through spiritual intelligence, auditors can interpret every work done so that auditors can express all their potential so that they can show optimal performance. Psychological well-being plays an important role in placing emotions in the right portion, and regulates the mood and is supported by psychological well-being aspects, which are expected to improve performance and carry out assignments.

Spiritual Intelligence moderates the influence of psychological well-being based on the theory of goal setting. In goal-setting theory, it explains that a person's behavior is determined by two cognitions, namely values and intentions (goals). If goals determine human business, the higher and more difficult the goals can be achieved, the higher the level of performance that is produced compared to goals that are easily achieved. Specific goals will result in a higher level of business than goals that are not clearly defined (vague goals). Incentives such as money, feedback, competition, and the like will not have an effect on behavior unless the incentive affects the setting and / or acceptance of difficult and specific goals. Spiritual intelligence is intelligence that shapes a person's character to be better and has deep meaning, and can be used as a benchmark to judge that one's way of life or actions is more meaningful than the way of life of others. These results are consistent with research by Rizkia \& Reskino (2015) which states that spiritual intelligence strengthens the effect of psychological well-being on auditor performance.

Based on Table 1., the results of moderation regression analysis show that the regression coefficient value of Role Stress $\left(\beta_{2}\right)$ is negative of -0.658 with a significance value of 0.000 and the regression coefficient value of the interaction variable $\mathrm{X} 2 . \mathrm{X} 3\left(\beta_{5}\right)$ is negative with a value of -29.550 with a significance value of 0.000 , then it shows there is a negative influence. This means that the Spiritual Intelligence variable is a moderating variable which weakens the influence of Role Stress on auditor performance. The test results obtained empirical evidence that $\mathrm{H}_{4}$ is accepted, meaning that spiritual intelligence weakens the effect of role stress on auditor performance. This means that individuals who have a certain level of stress can actually motivate someone to improve their performance and complete their work. However, excessive stress levels can have a negative impact which can lead to decreased performance, job dissatisfaction, and can lead to depression and anxiety. With good emotional management, the role stress experienced by auditors can be handled properly and it is likely that the auditor's performance will remain stable or increase. Through spiritual intelligence, auditors can interpret every work done so that auditors can express all their potential so that they can show optimal performance.

Spiritual Intelligence moderates the effect of role stress on auditor performance based on the role theory. In the role theory emphasizes the character of the individual as a social actor who studies behavior in accordance with the position he occupies in the work environment and society. The concept of role 
theory reflects the position of an individual in the midst of society in a social system that has a relationship with rights and obligations as well as authority and responsibility. Everyone has a role, whether in the family, work or social community, where in each of these roles they have different behaviors. Spiritual intelligence is intelligence that shapes a person's character to be better and has deep meaning, and can be used as a benchmark to judge that one's way of life or actions is more meaningful than the way of life of others. This result is in line with research conducted by Cendana \& Suaryana (2018) and Kembara (2014) which found that the results of Spiritual Intelligence weaken the effect of role stress on auditor performance.

\section{CONCLUSION}

Based on the results of research conducted, psychological well-being, role stress, spiritual intelligence and psychological well-being interactions, role stress, and auditor performance. This means that the good and bad performance of auditors can be affected by psychological well-being, role stress, and spiritual intelligence. Psychological well-being related to psychological well-being and role stress related to work pressure, if supported by spiritual intelligence, will certainly influence someone in the organization to improve the performance of the auditors of the Public Accounting Firm in Bali Province.

This research is only limited to auditors in Bali. Future studies can increase the research sample to get a broader area of generalization. For further researchers, it is suggested to expand the object of research, not only to the Public Accounting Firm, but also to the Supreme Audit Agency, the Inspectorate of Bali Province and the Representatives of the Bali Provincial BPKP. In addition, it is suggested for further researchers to develop this research by examining other factors that have more influence on auditor performance.

\section{REFERENSI}

Akimas, H. N., \& Bachri, A. A. (2016). Pengaruh Kecerdasan Intelektual (Iq), Kecerdasan Emosional (Eq), Kecerdasan Spiritual (Sq) Terhadap Kinerja Pegawai Inspektorat Provinsi Kalimantan Selatan. Jurnal Wawasan Manajemen, 4(3), 259-271.

Amalia, A. N. I. (2017). Pengaruh Role Stress Dan Emotional Intelligence Terhadap Kinerja Auditor Dengan Aspek Psychological Well-Being Sebagai Variabel Moderating. UIN Alauddin Makassar.

Amarin, H., \& Sukirman, S. (2017). Pengaruh Independensi, Kecerdasan Emosional, Dan Kecerdasan Spiritual Terhadap Kinerja Auditor. Accounting Analysis Journal, 5(2), 131-138. https:// doi.org/10.15294/aaj.v5i2.14369

Anjarini, A. D. (2018). Analisis Pengaruh Emotional Quotient, Intelligence Quotient dan Spiritual Quotient Terhadap Kepuasan Kerja dan Kinerja Guru di Sekolah Luar Biasa Negeri Batang. BBM (Buletin Bisnis \& Manajemen), 3(1).

Arfah, E. A., \& Dahniar, A. (2019). Moderasi Kecerdasan Emosional : Pengaruh Role Stress Terhadap Kinerja Auditor. ATESTASI: Jurnal Ilmiah Akuntansi, 2(2), 135-147. https:// doi.org/10.33096/atestasi.v2i2.327

Ariyanto, D., Firdaus, G. M., Sari, M. M. R., Dewi, A. A., \& Jhuniantara, I. M. G. (2020). How self control and situational pressure influence the tendency to 
receive gratification: An experimental study. International Journal of Criminology and Sociology, 9, 400-414. https://doi.org/10.6000/19294409.2020.09.39

Bowell, R. (2005). The 7 steps of spiritual intelligence The Practical Pursuit of Purpose, Success, and Happiness. Nicholas Brealey Publishing.

Cendana, D. K., \& Suaryana, I. G. N. A. (2018). Pengaruh Konflik Peran Dan Ketidakjelasan Peran Terhadap Kinerja Auditor Dengan Emotional Quotient Sebagai Variabel Pemoderasi. E-Jurnal Akuntansi, 22(2), 1141-1169. https://doi.org/10.24843/eja.2018.v22.i02.p12

Ermawati, M. D., Sinarwati, N. K., \& Sujana, E. (2014). Pengaruh Role Stress Terhadap Kinerja Auditor Dengan Emotional Quetiont Sebagai Variabel Moderating (Studi Empiris pada Kantor Akuntan Publik Di Bali). E-Journal Akuntansi Universitas Pendidikan Ganesha, 2(1).

Fogarty, T., Singh, J., Rhoads, G., \& Moore, R. (2000). Antecedents and consequences of burnout in accounting: Beyond the role stress model. Behavioral Research in Accounting, 12, 31-67.

Grece, Y., \& Latrini, M. Y. (2016). Pengaruh Kecerdasan Emosional, Kecerdasan Spiritual, Kecerdasan Intelektual Dan Independensi Pada Kinerja Auditor. Pengaruh Kecerdasan Emosi, 16(2), 1034-1062.

Iswarasari, D., \& Kusumawati, E. (2018). Pengaruh Konflik Peran, Ambiguitas Peran, Motivasi, Komitmen Organisasi, Dan Independensi Terhadap Kinerja Auditor (Studi Empiris pada Kantor Akuntan Publik di Surakarta dan Yogyakarta). E-Jurnal Akuntansi Universitas Muhammadiyah Surakarta.

Kembara, E. L. (2014). Pengaruh Struktur Audit, Konflik Peran, Ketidakjelasan Peran, dan Kelebihan Peran terhadap Kinerja Auditor. UNIVERSITAS KATOLIK WIDYA MANDALA.

Kurniawan, R. A. (2018). Pengaruh Konflik Peran Dan Ketidakjelasan Peran Terhadap Kinerja Auditor Internal (Studi Pada PSTNT Batan Bandung). JASa (Jurnal Akuntansi, Audit Dan Sistem Informasi Akuntansi), 3(1), 52-62.

Mappanyukki, A. (2019). Pengaruh Spiritual Intelligence dan Role Stress Terhadap Kinerja Auditor Dengan Psychological Well-Being Sebagai Pemoderasi (Studi Pada Inspektorat Provinsi Sulawesi Selatan). UIN Alauddin Makassar.

Murray, D. (1990). The performance effects of participative budgeting: An integration of intervening and moderating. Behavioral Research in Accounting, 104-123.

Nugroho, A. D. (2014). Pengaruh Tekanan Ketaatan, Kompleksitas Tugas, Pengetahuan Dan Persepsi Etis Terhadap Audit Judgment (Studi empiris pada KAP Surakarta dan Yogyakarta). Universitas Muhammadiyah Surakarta.

Pratama, A. A. N. (2014). Pengaruh Spiritualitas, Intelektualitas, Dan Profesionalisme Terhadap Kinerja Dosen Stain Salatiga. Inferensi, 8(2), 415436. https:// doi.org/10.18326/infsl3.v8i2.415-436

Putri, I. G. A. M. A. D., \& Wirawati, N. G. P. (2020). Influence of Intellectual/Emotional/Spiritual Intelligence, Independence, and Tri Hita Karana on Auditor Performance. Jurnal Ilmiah Akuntansi Dan Bisnis, 15(1), 8592. https:// doi.org/10.24843/jiab.2020.v15.i01.p08

Quilim, N., Taroreh, R., \& Nelwan, O. (2016). Pengaruh Kesejahteraan Psikologis Karyawan, Job Enrichment Dan Job Enlargment Terhadap Kepuasan Kerja 
Pada Pt. Bank Mandiri (Persero) Tbk Cabang Ternate Maluku Utara. Jurnal Riset Ekonomi, Manajemen, Bisnis Dan Akuntansi, 4(1), 1356-1368. https://doi.org/10.35794/emba.v4i1.12356

Rahayu, S. (2020). Pengaruh Psychological Well-Being Dan Kepemimpinan Transformasional Melalui Employee Engagement Sebagai Variabel Mediasi Terhadap Kinerja Pegawai Perumda Air Minum Tirta Ampera Boyolali [IAIN Surakarta].

Ramadika, A., Nasir, A., \& Wiguna, M. (2014). Pengaruh Role Stress, Gender, Struktur Audit dan Profesionalisme terhadap Kinerja Auditor BPK-RI Perwakilan Provinsi Riau. Jurnal Online Mahasiswa Fakultas Ekonomi Universitas Riau, 1(2), 1-15.

Rijal, F., \& Abdullah, M. W. (2020). Pengaruh Healty Lifestyle, Psychological Well Being, Dan Self Efficacy Terhadap Kinerja Auditor Dengan Task Complexity Sebagai Pemoderasi. Jurnal Akuntansi Kajian Ilmiah Akuntansi (JAK), 7(1), 2242. https:// doi.org/10.30656/jak.v7i1.1467

Rizkia, P., \& Reskino. (2015). Pengaruh Healthy Lifestyle, Role Ambiguity Dan Role Conflict Terhadap Job Satisfaction Dimediasi Oleh Job Burnout Dan Psychological Well-Being. E-Jurnal Ekonomi Dan Bisnis, 3(5), 1-30.

Rosally, C., \& Jogi, Y. (2015). Pengaruh Konflik Peran, Ketidakjelasan Peran, Dan Komitmen Organisasi Terhadap Kinerja Auditor. Business Accounting Review, 3(2), 31-40.

Ryff, C. D. (1989). Happiness is everything, or is it? Explorations on the meaning of psychological well-being. Journal of Personality and Social Psychology, 57(6), 1069-1081. https://doi.org/10.1037/0022-3514.57.6.1069

Sugiyono. (2017). Metode Penelitian Pendidikan (Pendekatan Kuantitatif, Kualitatif dan RED). Alfabeta.

Susanti, M., Hasan, A., \& A, A. A. (2017). Pengaruh Konflik Peran, Ketidakjelasan Peran, Dan Sesnsitivitas Etika Profesi Terhadap Kinerja Auditor Dengan Kecerdasan Emosional Sebagai Variabel Moderating. JOM Fekon, 4(1), 16891699.

Syafina, D. C. (2018). Kasus SNP Finance dan Pertaruhan Rusaknya Reputasi Akuntan Publik. https:// tirto.id/

Wiguna, I. P. I., \& Yadnyana, K. (2019). The role of working experience moderating the effect of emotional intelligence, intellectual intelligence, and spiritual intelligence on the ethical decision of tax consultants in Bali area. International Research Journal of Management, IT and Social Sciences, 6(3), 18-28. https://doi.org/10.21744/irjmis.v6n3.624

Wikanestri, \& Prabowo, A. (2015). Psychological Well-Being Pada Pelaku Wirausaha. Seminar Psikologi \& Kemanusiaan.

Winidiantari, P. N., \& Widhiyani, N. L. S. (2015). Pengaruh Konflik Peran, Ketidakjelasan Peran, Struktur Audit, Motivasi Dan Kepuasan Kerja Pada Kinerja Auditor. E-Jurnal Akuntansi Universitas Udayana, 12(1), 249-264.

Wiryathi, N. M., Rasmini, N. K., \& Wirakusuma, M. G. (2014). Pengaruh Role Stressors Pada Burnout Auditor Dengan Kecerdasan Emosional Sebagai Variabel Pemoderasi. E-Jurnal Ekonomi Dan Bisnis Universitas Udayana, 5(3), 227-244.

Zohar, D., \& Marshall, I. (2005). SQ: Connecting with our Spiritual Intelligence. 
NURSABILLA, T.Q., GAYATRI, SUPRASTO, H.B., \& SARI, M.M.R. SPIRITUAL INTELLIGENCE MODERATES...

Bloomsbury USA. 